ERATO 美濃島知的光シンセサイザプロジェクト事後評価（最終評価）報告書

【研究総括】美濃島 薰 (電気通信大学 情報理工学研究科／教授）

【評価委員】(敬称略、五十音順)

伊東 一良 (委員長 ; 大阪大学 /名誉教授、産学共創本部 /招聘教授)

大内 由美子（株式会社ニコン 光学本部第一設計部／部長）

須田 亮 (東京理科大学 理工学部物理学科 / 教授)

三尾 典克 (東京大学大学院 理学系研究科/教授)

評価の概要

ERATO 美濃島知的光シンセサイザプロジェクトは、エレクトロニクスと光技術との融合により、ス ペクトル強度が櫛状に等間隔に並んだ先端的光源（光コム）を、基盤的かつ革新的な計測が可能な新 技術群・機器へ進化させるとともに、これを使って様々な分野の革新的応用を開拓することを目標と している。美濃島薰研究総括をはじめ、各グループリーダーが培って来た、光コムに対する世界最高 レベルの知見と技術の蓄積をベースに、光コムとは関係性の薄かった応用分野との融合を図ること で、基礎科学としての知見獲得に留まらず、先端光計測における新たなキーテクノロジーとなる様々 な成果の創出を標榜した。

3 つの中核グループが設置されるとともに、要素技術研究および応用・実装に重点を置いた研究は、 4 機関に委託され、それぞれが中核グループと連携した研究が計画された。各グループは、光コムの制 御性を「周波数制御性」「モード制御性」、「時間・コヒーレント多モード制御性」の 3 つに特徵付 け、基盤技術の高度化と応用展開を分担し、互いに連携しながらも独自性を持ちつつ技術開発を行っ た。光コムに関する新たな技術の創出と、それらを用いた革新的応用の開拓に取り組んで得られた結 果を以下に示す。

前者では、高繰り返し Yb ファイバコム光源、デュアルコムファイバレーザー光源などの新規光コム 光源、複数の光コム間のコヒーレンス制御性を用いることで、画期的に光波制御の自由度を高めるコヒ ーレンスシンセサイザ技術など、光コムの物理的特性の深い理解に基づいた基盤技術が創出された。後 者では、従来比 100 倍の分解能かつ 1000 倍程度の高速性を実現しつつ、複素光学特性スペクトルの直 接評価も可能な汎用的固体材料物性評価手法、機械的走查が不要で位相情報も取得できる分光エリプソ メトリー、ダイナミックレンジ（精度／範囲）が 1000 倍向上し、フェムト秒レベルの単発現象の形状 情報も取得可能な瞬時 3 次元形状測定法、デュアル光コム顕微鏡、天文コムなど革新性に富んだ計測技 術が得られた。

研究期間の後段では、得られた個々の研究成果を学術論文や学会発表等で公表するだけでなく、社 会的、経済的価值に繋げる道筋を描くため、幾つかの成果については企業との共同研究など実用化に 向けた活動が実施された。特に上記で述べた成果のうち、汎用的な固体物性評価法、瞬時 3 次元形状 測定法、デュアル光コム顕微鏡では、それぞれ、高速高精度複素光学特性評価、撮像カメラ画角全域 における奥行きサブマイクロメートルの分解能、および強度・位相・蛍光・蛍光寿命計測において、 製品開発に繋がる競争優位性が確認され、潜在的なユーザーを意識した仕様のもと、応用分野側に一 歩踏み出した研究開発が行われた。特に汎用的な固体物性評価法は、企業をメンバーに加えた共同作 業により、外磁場印加に対する光学応答特性、すなわち磁気光学効果を高速高精度に評価するスーパ 
一分光計の一つの実施例として、製品プロトタイプ機にまとめられ、社会実装への道筋を示すところ まで踏み込んでいる。

以上より、ERATO 美濃島知的光シンセサイザプロジェクトは、戦略目標「情報デバイスの超低消費 電力化や多機能化の実現に向けた、素材技術・デバイス技術・ナノシステム最適化技術等の融合によ る革新的基盤技術の創成」に資する十分な成果が得られたと判断される。

\section{1. 研究プロジェクトの設定および運営}

$1-1$ ．プロジェクトの全体構想

本研究プロジェクトは、エレクトロニクスと光技術との融合により、光コムを光波の時間、空間、 周波数、位相、強度、偏光など、全てのパラメーターを自在に制御・操作寸る新技術群・機器「知的 光シンセサイザ」（革新的な特性を持つ光波の操作と高度な信号処理技術との融合による革新的なセン シング技術群・機器）へと進化させ、先端科学から社会応用に至る様々な場面において利用可能な知 的光源技術群を開発し、併せて広範な分野の「革新的応用の開拓」（未踏の応用分野開拓、革新的セン シング機器開発とその普及促進）を標榜し、2013 年度に発足したものである。

レーザー光周波数は数百 $\mathrm{THz}$ 程度と高く、この絶対值を計測するため、超短パルスレーザーを基に して開発された光コムは、極限的に精密な「周波数物差し」として知られており、2005 年のノーベル 物理学賞も、主としてこの性質が評価されたものである。光コムは現在に至るまで、最も精密な物理 量である光の周波数の様々な分野における利用を拓くと同時に、マイクロ波から光までの超ブロード バンド電磁波領域のコヒーレントなリンクを実現してきた。研究総括の美濃島薰氏は、光コムの持つ ポテンシャルにいち早く注目し、光コムを高精度距離計測に適用したが、これは「周波数物差し」以 外の応用では世界初であり、この分野の研究を牽引し続けている。

本プロジェクトは、研究総括の上記の先駆的業績を土台に、光コム技術において「周波数物差し」を 大きく超える新潮流を世界に先駆けて生み出すことを目指した。特に、各々のパラメーターにおける精 密性ばかりでなく、時間・空間・周波数軸の精密な関係性と、パルスレーザーの高い強度に基づく効率 的な非線形光学効果の発現を利用することにより、従来の計測技術ではトレードオフの関係にあった超 高速と超精密、高精度と広範囲という計測技術の制限を緩和し、超広ダイナミックレンジ、極めて広い 波長域などの従来技術を凌駕した計測技術の創出と、これによって生まれる広範な応用の開拓を目標と した。言い換えれば、光コムを従来の「周波数物差し」という捉え方から一歩踏み出し、光を自由自在 に操ることのできるツールの源と捉え、その実現と未踏な応用の開拓を目指したものであり、この斬新 なコンセプトのもとに研究を遂行する挑戦的なプロジェクトであった。このコンセプトは、美濃島研究 総括をはじめ、各グループリーダーが培って来た世界最高レベルの光コムに対する知見と技術の蓄積を 土台として創発されたものであり、分野の特長を生かした融合を通じて革新的な知識の創造を促し、こ れらの知識が先端光計測のキーテクノロジー形成に寄与するであろうと予見される。

このように、本プロジェクトを駆動した全体構想は、独自なコンセプトを掲げた挑戦的、創造的な取 り組みによる先進的かつ広範囲に応用可能な基盤技術の創出を目標とし、同時に更なる融合による発展 と様々な分野への波及を期待したものであり、ERATOにふさわしい構想であったと評価される。

$1-2$. プロジェクトの目標・計画

上記の全体構想に基づき、プロジェクトでは、光源技術と独自の光信号制御・処理、および情報取得 
手法を伴う光源利用技術の開発により「知的光シンセサイザ」を実現し、同時に、光コムの持つ特徵を

「周波数制御性」「モード制御性」、「時間・コヒーレント多モード制御性」の観点から整理し、これら を活用した「革新的応用の開拓」を計画した。ここで、「周波数制御性」は、光コムを「高精度物差しと して」利用する際に鍵となる顕著な特徵であり、同様に、「モード制御性」は、光コムを「単一スペクト ルレーザー光源群として」、また、「時間・コヒーレント多モード制御性」は、「パルス発振を規則的に繰 り返す多数の離散的スペクトルを持つレーザーとして」利用する際に鍵となる特徵である。

「知的光シンセサイザの開発」では、まず光コム周波数性能の極限的な高度化を目指し、(1)天文コム での利用や、受光器の飽和を防ぎ短期周波数安定度の向上を目的とし、モード間隔を $100 \mathrm{MHz}$ 級から $10 \mathrm{GHz}$ 級へ広げるパルス発振の高繰り返し化を実現、(2)実験室レベルでは、高い性能を持つ光コム制御 法の、より堅牢・シンプルで使い易い新制御法への変革と、これによる周波数制御法の高度化、(3)周波 数精度を 19 桁から 21 桁に向上させ、究極の光コムを実現するための精度の制限要因の解明、(4)制御法 の堅牢化や一体化技術を進めることによるロバスト化、小型化を目標としている。次に、(5) THz 領域に おける高精度な分光を実現する $\mathrm{THz}$ コム、6)文コムを実現する可視域にスペクトルの延びた光コム 波長域拡大を目標とし、さらに、(7)基盤的な光信号制御・処理技術の中でも応用性の高い手法の創造や、 8)光コムの持つ優位な特性を活用する新しい技術、例えば、等間隔のパルス列である光コムがその等間 隔性を保つ性質を利用する技術などの開拓を目標としている。

「革新的応用の開拓」では、時空間イメージング、天文、物性・燃焼計測への応用を中心として基盤 技術を確立し、光コムの利用が画期的な応用分野創出に繋がるように計画されている。光コムの「時間・ コヒーレント多モード制御性」を大きく向上させ、計測に新しい自由度を導入する時空間イメージング では、超短パルスの時間・空間・周波数の精密な関係性を融合することで、物体の瞬時 3 次元形状測定 を実証する計画が立てられた。先行研究では、分解能はパルスの包絡線で決まる数 $\mu \mathrm{m}$ 、測定範囲は于 ヤープ量でリミットされ、数 $\mathrm{mm}$ 程度が限界であったが、異なるパルスの位相レベルの相関を用いるこ とにより、計測分解能数 $\mathrm{nm}$ と計測範囲数 $\mathrm{m}$ 、且つフェムト秒領域の時間分解能を両立させ、計測にお けるトレードオフ解消を実証することを目標としている。一方、この同じ「制御性」を利用し、デュア ルコム分光を先行例の無い「時間分解デュアルコム分光」へと拡張し、全く新しい応用を創出する研究 が計画に組み込まれている。

物性・燃焼計測技術の開拓では、「モード制御性」の利用技術の開発が計画された。具体的には、光コ ムによる周波数絶対值が判別可能な狭線幅光源を用い、分子識別能力や検出感度を向上し、エアロゾル が混在する現実的サンプルでも分析可能な $\mathrm{THz}$ 分光法の実現を目指した。様々な分子を詳細に識別し 定量するためには、高分解・高確度・広帯域の三拍子が揃った分光法の開発が必要であり、光コム利用 技術の高度化で得られた技術を活用することが計画された。また、この制御性の利用では、光コムが多 数の離散スペクトル (コムモード) を持つことを使い、イメージ画素とコムモードを 1 対 1 対応させ、 イメージ情報をコムモードに重畳させた後に、モード分解した振幅/位相スペクトルから、一括して、ス キャンレスでイメージを取得する画期的な顕微鏡への応用も計画された。

「周波数制御性」技術の大幅な革新にもとづき、宇宙論への応用を目指寸天文コムの開発も計画され た。既設の分光計と互換可能な高繰り返し周波数（目標 $10 \mathrm{GHz}$ ）を有し、かつ長い時間メンテナンスフ リーな光コムを実現するため、光源の開発で述べた高繰り返し化やロバスト化などの成果の利用を前提 とした。

なお、上記以外の応用分野として考えられる、ライフサイエンス分野や、光情報処理・偏光計測・フ アイバーセンシングなどの光応用計測分野に対しても、光シンセサイザや光コムを導入することを視野 に入れ、随時研究計画を見直すことも行われた。 
以上により研究期間における目標ならびに計画の設定は適切であると認められる。波及効果が表れる まで、ある程度の時間を伴うことも思量されるものの、このような取り組みは得難く、本プロジェクト の役割と意義は大きいと判断される。

\section{$1-3$. プロジェクトの運営}

本プロジェクトには、「知的時空間統合化グループ」(電気通信大学)、「周波数極限化グループ」（産 業技術総合研究所）、「テラヘルツ・広帯域スペクトル操作グループ」（徳島大学）の 3 つの中核グルー プが設置されるとともに、要素技術研究および応用・実装に重点を置いた研究は、4 機関（慶應義塾大 学、横浜国立大学、国立天文台、ネオアーク株式会社）に委託され、中核グループと連携した研究が実 施された。各グループは、有機的に連携しながら研究を推進したが、研究員の専門分野の多様性や、各 グループの人数などのバランスは妥当であり、運営は効果的であった。また、多様な人材の連携を自主 的に働かせる仕組みが作られ、実施機関を越えた交流も盛んであった。

新技術の開発とともに、応用事例を提示寸ることにより、本プロジェクトの成果が広く認知され、普 及につながるという考えに基づく運営が推進された。特にプロジェクト期間の後段では、得られた個々 の研究成果を、学術論文や学会発表で公開するだけに留まらず、潜在的なユーザーへの訴求効果を高め るべく、企業との共同研究など、実用化に向けた活動が実施された。また、汎用的な固体物性評価に向 けて拡張されたデュアルコム技術の実装（「スーパー分光計」）、瞬時 3 次元形状測定法の開発、デュ アル光コム顕微鏡の開発、天文コム 2 号機の開発および同機の国立天文台岡山天体物理観測所（現・国 立天文台八ワイ観測所岡山分室）への設置では、プロジェクトの参画機関内の連携強化により、研究開 発の効率化・加速化が図られた。

電気通信大学に置かれたヘッドクォーターは、研究総括により適切に運営され、予算管理および研究 計画策定や、成果の取り纒めとともに、研究開発戦略を定めるための企業ニーズの調査も実施され、各 種調整等を含む研究支援の役割が十分に遂行されたと判断される。

若手研究人材の育成も適切に行われた。実際、領域（全体）会議や海外研究者を招聘し実施された会 議等では、若手研究者や学生も参加するポスターセッションが頻繁に行なわれ、自らの分野に近い内外 の専門家らとの密な議論を行うという、次世代 PI（研究グループの主宰者）としての力量養成につなが る場が数多く設けられた。

2017 年度実施の事後評価（予備評価）を受けて、研究の一層の発展性を考えると性質の異なるグルー プとの交流も重要であることが認識され、企業を含めより多様な関係性の構築が模索された。数多くの 企業との技術的な議論により、成果のまとめに市場視点が加味され、研究開発課題の重点化の際には良 い影響が現れた。また、予備評価において評価委員から、本プロジェクトで構築されてきた連携体制は、 光コム関連の研究拠点として、近未来的にも遠未来的にも極めて高い発展性を有しており、プロジェク 卜終了後も、何らかの形で維持発展することが望ましいとの指摘が行われた。これを受けて、プロジェ クト終了後の研究推進案が検討され、内閣府の地方大学・地域産業創生交付金事業（徳島県『次世代“光” 創出・応用による産業振興・若者雇用創出計画』）の支援を受けることになり、徳島大学に 2019 年に設 置された「ポスト LED フォトニクス研究所」には、テラヘルツ・広帯域スペクトル操作グループが中 心となって (同研究所の所長 : 安井グループリーダー)、本プロジェクトメンバーが創出した人的ネット ワークや、技術資産の継承・発展が可能になった。

また、美濃島研究総括は、2019 年度より、電子情報通信学会の超高速光エレクトロニクス研究会の委 員長に就任したが、光コムや超短光ファイバレーザーおよびその応用を重点トピックスとするフォーラ 
ムの一つを、本プロジェクトの研究成果を周辺分野に融合・発展させる場の一つであると捉え、活動す る意向を示している。

以上のように、プロジェクトの運営はプロジェクト実施期間全体、さらには終了後にも目が向けられ ており、的確であったと判断される。

〔研究プロジェクトの全体構想〕〔研究プロジェクトの目標・計画〕〔研究プロジェクトの運営〕

a（的確かつ効果的である）

2 . 研究の達成状況および得られた研究成果

$2-1$. 知的時空間統合化グループ

本グループは、主として光コムの利用技術の高度化に取り組み、様々な応用に適した光コム光源の開 発と、光コムの特性を十分に生かした利用技術の開発を目標とした。同時に、これらの成果を広範な分 野における新規応用の開拓につなげるための応用基礎技術の開発も目標とした。

光コム光源の開発では、汎用的な $\mathrm{Si}$ 検出器の使用が可能な波長 $1 \mu \mathrm{m}$ 帯の $\mathrm{Yb}$ ファイバコムを開発す ることにより、高繰り返し化技術の実証を行った。周波数絶対值の付与された $750 \mathrm{MHz}$ の高繰り返し と、広範な応用に適用できる増幅出力 $10 \mathrm{~W}$ の出力が達成され、レーザー共振器直接出力を用いて制御 されたファイバコムとしては、最も高い繰り返しが実現された。また、光コムの標準的光源として信 頼性の高い Er ファイバコムにおいても、その高制御性を保ったまま、任意の高繰り返し化を実現する ためのモードフィルタリング技術に取り組み、広帯域なフィルタリングが可能な空間光学系に基づい た技術、およびロバスト化、コンパクト化が可能なファイバ光学系を利用した技術を確立し、10 倍以 上の増倍率で $\mathrm{GHz}$ レベルの高繰り返し化、40dB 以上のサイドモード抑制が可能な高品位光源を実現 した。

実用的な光源開発においては、当初の目標を越えて、1台のモード同期レーザーから $f_{\text {rep }}$ （コム間

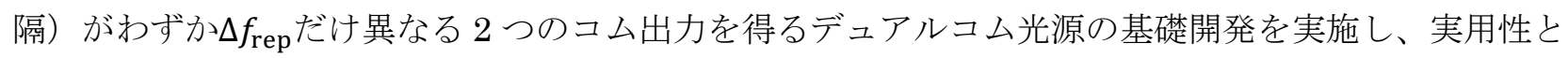
高品位性を両立させた適用性の広い光源を開発した。具体的には、独自の共振器設計によって、2つの 光コムに共通な原因で発生する雑音を抑制し、高コヒーレンス、高安定性を兼坟備えたデュアルコム ファイバレーザーを開発した。実際、 $\Delta f_{\mathrm{rep}}$ が $1.5 \mathrm{~Hz}$ の設定のデュアルコム光源において、共通雑音の 抑制効果により標準偏差 $0.14 \mathrm{~Hz}$ の範囲で一定となる安定度を確認したが、この光源では、デュアル コム測定可能な帯域幅 $479 \mathrm{THz}$ （3888nm）が担保され、高性能と実用性を備えている。世界初のキヤ リアエンベロープ周波数 $\left(f_{\mathrm{CEO}}\right)$ 検出・制御や、可視から中赤外に至る波長域拡大の成果も示されてお り、材料特性評価、イメージング等のデュアルコム分光法の実用化に向けた大きな進展と評価でき る。開発されたデュアルコム光源は、プロジェクト内の成果融合によって、デュアルコム顕微鏡技術 へ応用され、有用性が確認されたが、これはプロジェクト内で横断的かつ多岐にわたり創出されたデ ユアルコム分光応用技術に対して、その実用性を画期的に高める光源が生みだされたことを示してい る。

また本グループは、制御された複数の光コムを同期制御・合成することで、光波のコヒーレンスを 自在に制御・活用する新たな光源・利用技術が拓かれることを示した。実際に、高速な偏光変調光コ ムの生成・検出技術や、横空間（ビーム横モードの空間分布）と時間軸の双方で位相制御がなされた 高機能光源“光渦コム”発生技術を開発している。前者は、後述の分光エリプソメトリーや瞬時 3 次元形 
状測定で活用されている。これらは、光コムの安定なコヒーレントパルス列という時間軸上の特性 を、複数の光コムの同期制御・合成に積極的に活用する初の試みであり、光波の制御・操作技術、お よび新規な高度コヒーレント光源技術として、最先端の光技術分野に大きなインパクトを与えてい る。

パルス間隔が自律的に等しく保たれる光コムの時間的性質を有効利用する、アダプティブコム技術 においても、距離測定における主要な不確かさの要因となる、空気屈折率の環境変化を高精度に補正 する手法が開発され、広く用いられている経験式による空気屈折率補正法を凌駕する精度 $\left(10^{-9}\right)$ を実 証した。このような環境変動の自己補正技術は、精密ものづくり産業の計測・加工における課題であ る精密空調の必要性を大幅に緩和し、省エネルギー、低炭素化に大きく寄与可能である。更に、安定 環境での精密な距離測定から大きく脱皮して、実用的な環境下で生ずる急激な空気摇らぎを、自律的 かつリアルタイムに補正して、高精度かつ広範囲な測定を実現する研究に取り組んでいる。具体的に は、数 10〜100m 離れた試料のサブマイクロメートル絶対形状計測に応用可能な技術を実現してい る。安全を担保する構造モニタや距離センシング、ビッグサイエンスに必要とされる悪環境下や、遠 隔での形状計測への寄与、更により信頼性の高い技術として確立すれば、LiDAR 技術にも応用できる と考えられる。

光コムの時間軸特性を生かした応用技術の開拓は、これまでほとんど行われてこなかったが、本グ ループでは、従来のデュアルコム分光法を「時間分解デュアルコム分光」へと拡張発展させることに より、デュアルコム分光法の固体物性研究への応用が可能であるとの着想をもとに、当初の目標を越 えた展開を行っている。この手法では、光学結晶や半導体などの様々な固体試料の複素光学特性を直 接取得することが可能であり、広帯域スペクトル特性と、高時間・周波数分解能を両立した高速測定 が可能な物性評価ツールの実現が期待される。さらに、位相屈折率の絶対測定等の単一の特性取得の みならず、材料の屈折率と厚さおよびその分布の同時測定など、より適用性が広く、汎用的な物質材 料評価手法としての開発を進めている。また、定常的な特性のみならず、外場印加に対する光学応答 特性の高速評価手法への拡張を進め、磁気光学効果計測に適用した。さらに、開発したデュアルコム 分光法のみを用いて、誘電率テンソル成分を直接評価する手法を開発し、物質材料やデバイスの多項 目の特性評価を包括的に行うことが可能な強力な計測・評価手法となる可能性を示した。本基礎研究 成果は、プロジェクト最終年度に新たに開始したプロジェクト内連携によって、「スーパー分光計」の ひとつの事例として、具体的なユーザーの想定できる磁気光学効果測定装置の製品プロトタイプ機開 発に至っており、25nm の波長範囲を波長分解能 $0.01 \mathrm{~nm}$ 、ファラデー効果測定分解能 $0.01 \mathrm{deg}$ 、一点 の測定時間 $7 \mathrm{msec}$ での高速・高精度測定を実証した。これは、光コム応用の社会実装に向けての大き な一歩と評価できる。

さらに、モード同期ファイバレーザーからのチャープコムを利用するパルス間スペクトル干渉に基 づく広範囲・高精度・超高速な瞬時 3 次元形状測定法が、本グループで開発されている。実際に、3 次 元段差形状測定、粗面や内部構造のイメージングに適用し、光コムの精密な間隔のパルス列を用いる ことで、計測における根源的なトレードオフの関係が解消できることを実証した。ダイナミックレン ジ (精度 /範囲) が $10^{6}$ 以上、時間分解能数 $10 \mathrm{fs} \sim \mathrm{ps}$ (パルス幅に依存)、取得レート数 Mfps（繰り 返し〜Gfps）の革新的な計測の可能性を実証している。また、顕微から望遠までの自由度を有し、内 部非破壊測定や強度および位相像計測が可能であることも示している。これは、世界で初めて、光コ ムの高精度な周波数・位相制御性を、パルス内光電場波形制御に適用し、全光演算手法すなわち光ヒ ルベルト変換を行う信号処理技術を実現した結果得られた成果である。この技術により、マイクロメ ートルの精度かつメートルの測定範囲を同時に実現する極めて適用性の広い超高速の 3 次元イメージ 
ング手法が実証されたことになる。本方法は、撮像光学系の最適化により、非常に小さな物体から、 大きな段差や長辺と短辺の比が大きな物体の高速 3 次元形状の精密計測、単発現象の瞬時イメージン グなど、多種多様な応用が期待される。

以上のように、光コムの多次元・高精度・広ダイナミックレンジ・高制御性を十二分に活用する技 術を開発し、光波の制御性を画期的に高める「知的光シンセサイザ」実現に大きく前進している。さ らに広範な「革新的応用」に向けた基盤技術を提示することに成功している。当初の目標を越えた展 開もあり、いくつかの有望な方向性が見出された。市場ニーズが見込め早期実用化の可能性が高いと 判断された課題は、周囲に広がる応用分野側に一歩踏み出して、その可能性を具体的に示すととも に、企業メンバーと共同で製品プロトタイプを開発することにより、社会実装への道筋を示すところ まで踏み込んでいる。

このグループでは、以上のように、多数の画期的な技術の開発に成功している。これらは、櫛状の スペクトル強度よりは多数の周波数モードのコヒーレントな関係性に着目し光コムの持つ光波の制御 性を総合的に利用しょうとした点で先駆性があり、更なる発展が期待できる。

$2-2$. 周波数極限化グループ

本グループは、主として光コム自体の高繰り返し化、新たな制御法の開発、安定度の向上に関する基 盤技術の高度化を研究しつつ、天文、分子科学、温度計測分野への光コム適用を目指した。そのための 重点研究項目として、天文コムの開発、デュアルコム分光の分解能の向上と測定対象の拡大、光コムの 新たな安定化技術の提案、および極限的周波数安定度の追求を設定し、研究を実施した。

天文コムの開発では、横浜国立大学、電気通信大学、国立天文台との連携により 1 号機を開発して、 国立天文台岡山天体物理観測所に設置し、高分解能分光器 HIDES-F での天文コムのスペクトル評価や 試験観測を行った。引き続き、顕在化した課題を解決する 2 号機の開発を行い、再び岡山天体物理観測 所に設置して、同様の評価を行った。2 号機では、堅牢な Er ファイバレーザーを光源とし、フィネス 100 という扱いやすい光共振器により $30 \mathrm{GHz}$ の間隔周波数と不要モード抑圧比 $60 \mathrm{~dB}$ 超を実現すると ともに、スペクトル広帯域化と可視領域への波長変換のため、高非線形ファイバとチャープド周期分極 反転ニオブ酸リチウム導波路素子を併用した新光学系を開発した。主要な光学系をほぼ偏波保持ファイ バ光学系としたことで、より高い堅牢性を実現し、最終的に発生させた可視広帯域光において、間隔周 波数 $30 \mathrm{GHz}$ 、不要モード抑圧比 $40 \mathrm{~dB}$ を達成した。波長範囲の詳細は、可視波長域の $57 \%$ に相当する 350〜405nm、455〜 535nm および 680〜820nm の帯域であり、これは現在報告されているうち、10 $\mathrm{GHz}$ 超の繰り返し周波数を持つもので、最も広帯域な可視光コムであった。このように、世界最高の性能を 持つ天文コムを実現したが、天文コムは、既存の天文台の性能を飛躍的に改善し、天文観測の要となり 得る技術であるため、研究成果が国内外の多くの天文台に波及する可能性がある。また、民間企業への 技術移転も期待されるので、この意義は大きい。実施機関の取組みが、今後も引き継がれ、継続してい くことが望まれる。

デュアルコム分光の分解能の向上と測定対象の拡大では、その応用が重要かつ多岐にわたるため、徳 島大学、横浜国立大学、および慶應義塾大学と連携・協力し、研究が実施された。本グループは、主体 となって、アセチレン分子 $\left(\mathrm{C}_{2} \mathrm{H}_{2}\right)$ の遷移双極子モーメントや圧力効果のオルト・パラ依存性の測定等の、 分子科学関連研究、ガスの精密温度測定に関寸る研究を実施した。その結果、前者では、圧力に対する 分子吸収スペクトル線幅拡がりに、オルト・パラ依存性が現れることを確認し、後者では、デュアルコ ム分光の高速・精密・広帯域という長所を活かし、分子の多数の吸収線の強度分布から精密に熱力学温 
度を測定する方法を考案し、0.3 ${ }^{\circ} \mathrm{C}$ 程度の温度測定精度を示した。これは、ボルツマン定数などの物理 定数のみから温度を導く方法であり、2019 年にボルツマン定数が国際単位系（SI）の定義值となったこ とから、熱力学温度を測定する「一次温度計」を提供する技術になりうる。現在一般的には、高精度な 熱力学温度計測では、測定不確かさが数 $\mathrm{mK} \sim 10 \mathrm{mK}$ レベルと、他の熱力学温度計に比べ最も小さい音 響気体温度計（AGT）が用いられているが、本グループで開発した手法は、システムの高度化により、 既存の AGT と同等の高精度な温度測定が可能であると予想される。加えてデュアルコム分光の高速性 から、過渡的な状態の気体温度を高い時間分解能で連続的に測定できる可能性も十分にあり、燃焼の素 過程などの非平衡状態や、過渡状態の温度測定にも応用可能と考えられるなど、産業界での応用が見込 め、今後の発展が期待される。

光コムの顕著な特徵は、 $\mathrm{n}$ 本目のモードの周波数 $v_{n}$ が $v_{n}=\mathrm{n} ・ f_{\mathrm{rep}}+f_{\mathrm{CEO}}$ という簡単な式で記述でき、 同時にこれが厳密に成り立つことである。光コムを使いこなそうとするとき、 $f_{\mathrm{rep}}$ と $f_{\mathrm{CEO}}$ の二つのパラメ ーターの制御が、システムの安定性やコストなどを決定すると言っても過言では無い。本グループは、 光コムの新たな安定化技術の提案に関する研究を行い、特長のある制御方法を多く生み出した。光コム の $f_{\mathrm{CEO}}$ をゼロにするオフセットフリーコム技術、および $f_{\mathrm{rep}} / N$ （N は整数）に安定化するための技術で ある。1つは、音響光学変調器（AOM） を用いフィードバックおよびフィードフォワード法によって $f_{\mathrm{CEO}}$ のゼロを含む任意周波数へ安定化する技術であり、他方は、 $f_{\mathrm{CEO}}$ と同時に検出される $f_{\mathrm{rep}}= \pm f_{\mathrm{CEO}}$ を 互いに位相同期する Dual-beat phase-lock 法の開発に基づいた半整数光コム、およびオフセットフリー コムの開発であった。さらに、励起光強度制御により光コムの全ての周波数制御を行う全光制御型光コ ムに関する研究も実施した。全光制御型光コムは、PZT（圧電素子）等を共振器長制御に用いて周波数 制御を行う場合と同等の性能が確認されたが、価格、モード同期の始動性に優れ、堅牢性においても有 利であり、光コムシステムの使用を促す技術として有用である。「光コムの新たな安定化技術」はいずれ も独創的な技術であり、多様な応用システムへの搭載により、世界標準的に使われていく可能性のある 技術群であると評価される。

極限的周波数安定度の追求では、光コムの雑音について正確に理解し、世界最高の周波数安定度を持 つ光コムを開発するために行なわれたが、これまでに、光ファイバが発生する位相雑音に関して、1 秒 平均において $10^{-21}$ の周波数安定度まで評価する手法が開発され、 1 秒平均で $10^{-20}$ 程度の周波数安定度 を持つ光ファイバ干渉計が実現された。

本グループにおいて、本プロジェクトのメンバーらが世界に先駆け開発してきたファイバコム技術を 進化させ、究極の安定度や従来の常識を超えた応用を目指寸過程で得た成果は、いずれも先行研究・競 合研究を凌駕する着実且つインパクトの高い研究成果である。また、今後の発展が期待されるデュアル コム分光を利用したガス温度測定の研究は、当初の目標を越えた研究である。天文コムは高度化・先鋭 化された光コムの端的な応用例であり、デュアルコム分光の分子科学関連研究への応用とともに、プロ ジェクト内の連携が有効に機能し成果をあげた例として、運営面からも評価される。

\section{$2-3$. テラヘルツ・広帯域スペクトル操作グループ}

本グループでは、光コムの波長域の拡大を目的として、テラヘルツ $(\mathrm{THz})$ 波領域の発生と利用技 術の高度化や汎用化、テラヘルツ分光を中心とした応用が展開された。近赤外領域では、光コムに潜 在する究極的な光源としての能力を顕在化させる新しい応用が研究された。 
$\mathrm{THz}$ コムに基づいた分光計測技術デュアル $\mathrm{THz}$ コム分光法をさらに高精度化するためには、 $\mathrm{THz}$ コムのモードの線幅に対して間隔が非常に大きいという本質的問題点（超離散マルチ・スペクトル 性）の解決が必須である。その手段として、モード同期周波数を走査することにより、THz ムムモ ドを横ずらししながらスペクトル波形を逐次取得し、最終的に全てのスペクトルを重畳させて $\mathrm{THz}$ ムモードの間隙部分を補完し、ギャップレス化するギャップレス・デュアル $\mathrm{THz}$ コム分光法が開発さ れた。さらに、 $\mathrm{THz}$ コム・パルス列の極めて安定な時間周期性を、離散フーリエ変換に取り込むこと により、デュアル THz コム分光法と同等以上の高精度性を実現しながら測定データ量を大幅に削減す る、離散フーリエ変換 $\mathrm{THz}$ 分光法の開発が実施され、 $\mathrm{THz}$ 領域のみならず近赤外領域における高分解 分光においても、この技術の有用性が実証された。また、実用化時の装置コストを意識し、非制御レ ーザーの利用を可能とするアダプティブサンプリング式デュアル $\mathrm{THz}$ コム分光法が開発された。これ は、レーザー間タイミングジッターを反映したアダプティブ・クロックが生成され、それに基づいた 信号取り込みにより、タイミングジッターによる時間軸の非線形性が補正され、従来の安定化制御デ ユアル・レーザーと同等以上の分光性能が達成可能であることが実証された。これは、デュアル $\mathrm{THz}$ コム分光法に汎用性が付与されたと位置づけられ、実用システムへの実装が期待される。

$\mathrm{THz}$ 分光の応用展開では、デュアル $\mathrm{THz}$ コム分光法において、 $\mathrm{THz}$ 波の有する極性ガス指紋スペ クトル判別能とエアロゾルに対する散乱耐性をうまく利用することにより、煙が混在したガスの濃度 を ppm オーダーで実時間濃度モニタリングすることに成功した。光周波数差が $\mathrm{THz}$ オーダーに設定 された 2 台の光周波数シンセサイザの差周波信号を抽出することにより、連続チューニングが可能 な、周波数可変型 $\mathrm{THz}$ シンセサイザを構成し、アセトニトリルとその同位体の分子種識別に応用し、 ガス分析手段としての有用性を確認している。

一方、広帯域スペクトル利用イメージングに関する研究では、特徵的なイメージング手法の開発に 取り組み、以下のような代表的成果を得た。

光コムが多数の離散スペクトル（コムモード）を持つことから、回折格子などの波長分散素子を利用 した波長/空間変換によってイメージ画素とコムモードを 1 対 1 対応させ、イメージ情報をコムモードに 重畳させた後に、モード分解した振幅位相スペクトルから一括して読み出せば、スキャンレスでのイメ ージ取得が可能になることが着想され、実証された技術である。実際、この技術を顕微鏡に適用し、顕 微計測に共焦点性、スキャンレス性、位相コトンラスト性が同時に付与可能であることを世界で初めて 実証した。更に、デュアル光コムビートと高密度周波数多重化イメージングをうまく融合することによ り、デュアル光コム顕微鏡をインコヒーレントな蛍光顕微鏡に拡張した蛍光デュアル光コム顕微鏡を実 現し、点型検出器で一括取得された周波数多重化信号から、蛍光テストチャートサンプルの蛍光振幅画 像および蛍光寿命画像を得るマルチモーダルイメージングが可能であることを実証している。スキャン レス性から、全ての画素に同時性が担保されて時空間動態可視化が可能であること、蛍光強度と蛍光寿 命の同時計測が可能で蛍光波長の重なった生体分子発光を蛍光寿命から分離可能であることから、細胞 の動態観察において競争優位を有し、実用化が期待されている。

デュアル光コム分光法の持つ、短い測定時間で広波長域を高い波長確度、および周波数分解能で計測 可能であると同時に、光の振幅/位相情報を直接取得可能であるという特徵を活用し、機械的偏光変調 を必要としない高精度分光エリプソメトリーが実現された。この結果は、光コムのモード制御性を利 用し、得られた成果である。振幅・位相の直接測定が可能であり、波長分解能が $1.2 \times 10^{-5} \mathrm{~nm}$ と従来の 100 倍以上であるとともに、計測スループットが大きいという特徴から、数十万点以上の取得データ からのモデル解析フィッティングが可能であり、計測精度向上が期待される。 
これらの研究成果はいずれも新規性に富み、さらなる発展が期待できる。特に、ギャップレス $\mathrm{THz}$ デュアルコム分光法や離散フーリエ変換 $\mathrm{THz}$ 分光法、アダプティブサンプリング法などは、革新性と 簡便性を同時に備えており、今後の実用化や、更なる新分野への展開が期待できる。また、デュアル 光コム顕微鏡やデュアルコム分光エリプソメトリー法などは、材料評価やプロセス評価などの分野に おいても、新しい利用法に繋がる可能性がある。このように本グループにおいても、目標に対する達 成度は十分であり、一部は、当初計画で想定されていた目標を大きく上回る成果が得られたと判断さ れる。

以上に基づきプロジェクト全体の研究成果を俯瞰すると、様々な応用に適した光コム光源の開発及び 利用技術の高度化と共に、この光源技術を利用した新規応用分野の開拓に取り組んだ結果、光コムの普 及において先導的な役割を果たす多くの成果をあげたことが解る。具体的には、高性能および汎用光コ ム光源、精密分光、距離・形状計測、材料評価、天文観測、顕微計測などの分野において、様々な計測 ・ 制御・信号処理を含めた独創的な技術開発が行われたと認められる。

学術的には、当該分野はその関連論文発表件数が増加を続けている先端的な分野であるが、本プロ ジェクトの研究成果に関わる論文数(81)、発表件数(699)、招待講演数(196)、知的財産権(22)の数 (2019.11.30 時点) などは十分であり、本研究課題の目標が十分に達成されたと判断される。また、 一部では期待以上の成果が得られたと認められる。成果は多方面に広く波及効果があり、本プロジェ クトにより築かれた国内外の連携体制が拡大発展し、引き続き新たな分野の創出も期待されよう。

〔研究の達成状況および得られた研究成果〕 $a+（ 十$ 分に高い水準にある）

3 . 研究成果の科学技術、社会・経済への貢献

$3-1$. 科学技術への貢献

極限的に精密な光周波数計測の手段である『周波数物差し』としての光コムの概念は、プロジェクト 開始以前から確立されていたが、本プロジェクトでは、光コムを、光波のあらゆる制御性を画期的に高 めるツールとして捉え直すことによって、従来の『周波数制御性』にも発展的・拡張的な意義を与える と同時に、『モード制御性』、『時間・コヒーレント多モード制御性』の観点から、光コムが本質的に有す る優れた特性を余すことなく引き出し、利用する技術群を実現した。同時に、光コム技術自体の新展開 や、他分野との融合的な発展のためには、応用技術以外に、誰もが利用できる光コム光源自体が必要で あったが、本プロジェクトでは、ファイバレーザーをベースとした複数種の光コム光源や、デュアルコ ム光源、オフセットフリーコムなどが開発されており、応用を拓く成果であるとともに、光コム分野の 進展にとっても革新的な成果であった。これらの研究成果はいずれも独創的であり、国内外を問わず、 その評価は非常に高く、申し分がない。これは、81 編の査読付き論文、699 件の国内外一般講演 (2019.11.30 時点) などの成果発表とともに、研究総括が、光関係分野で世界最高峰の会議である CLEO 国際会議で、2017 年の Optical Metrology 分野の Tutorial Talk【基調講演に相当】や、2020 年（予定） の会議全体の Plenary Talk、および 2019 年の MIT Hermann Anton Haus Lecture を依頼されたこと を始めとして、プロジェクト期間に全体で、196 件の Plenary・基調講演・招待講演を行ったことから も裏付けられる。

プロジェクトでは、研究の芽を育み、新たな分野を創出する勢いと方向性があったが、これはプロジ 
エクト期間終了近くになっても維持された。実際、論文数、発表件数は予備評価後に倍増に近い伸びを 記録し、達成した光コムの性能など成果にも、大きな進展がみられた。光コムの研究は、基礎と応用、 技術の開発と実践など、さまざまな対立または相補する要素を含んでいる。プロジェクトに参画するメ ンバーが、目標を共有して位相を揃えることが難しい中で、研究総括および各グループリーダーの明確 で見通しの良いガバナンスにより、さまざまなレベルの連携が動的に形成され、研究成果に結びついた と考えられるが、このことの科学技術への貢献は大であったと判断される。

\section{$3-2$. 社会・経済への貢献}

当該プロジェクトでは、企業への技術紹介や人材の育成などが精力的に行われ、この分野と技術の 裾野を広げることに大きく貢献した。研究期間の後段では、得られた個々の研究成果、方法論を、プ ロジェクトを表象する成果としてまとめ、将来の社会的、経済的価值にどう繋げるかが議論され、幾 つかの成果については、企業との議論や共同研究など実用化に向けた展開が実施された。特に、拡張 されたデュアルコム分光法の汎用的な固体物性評価装置である「スーパー分光計」への実装、瞬時 3 次元イメージング法、デュアル光コム顕微鏡では、それぞれ、高速高精度複素光学特性評価、撮像力 メラ画角全域における奥行きサブマイクロメートルの分解能、強度・位相・蛍光・蛍光寿命計測にお いて、製品開発に繋がる有望な方向性が見いだされた。また、潜在的なユーザーを意識した仕様のも と、応用分野側に一歩踏み出した研究開発が行われた。特に、前述のデユアルコム分光法の固体物性 研究への応用で開発された汎用的な物質材料評価手法に関しては、企業をメンバーに加え共同作業を 実施することにより、外磁場印加に対する光学応答特性、すなわち磁気光学効果を高速に評価する光 コム分光計の製品プロトタイプ機を開発することで、社会実装への道筋を示すところまで踏み込ん だ。

光コムは、一見して興味深いが、一方で、先端的光技術や高周波エレクトロニクス技術などを必要と するため、取り扱いが難しく厄介な代物であると捉えられがちであり、このような状況はレーザーの黎 明期と似ているが、やがて本プロジェクトの成果は社会・経済に浸透し、多数の理解者や利用者を得て、 その波及効果が現れるものと期待される。実際、上述の使いや寸い光コムや制御法が開発されており、 これらが普及することにより、プロジェクトで開発された様々な応用技術、これらを実装した機器の発 展が期待できる。需要とのバランスが要となるが、プロジェクトで開発された光コム光源が事業化され て、使いや寸い安価な光コム光源が供給されると、新規参入者が増加し、この分野の更なる発展が期待 できる。このように、光コム光源の事業者による供給は、この応用技術・製品の更なる研究開発を喚起 し、社会・経済への循環的な貢献が期待できる。この点を鑑みれば、プロジェクトの後半で始まった、 光コム事業を手がけるネオアーク株式会社との成果実装を目的とした連携は効果的であった。

このような、光コム自体の低コスト化や提案された応用のニーズが顕在化すれば、様相が一挙に変わ り、短期間に成果の社会実装が実現できる可能性もあるので、引き続きで企業化の努力をしていく必要 もあると思われる。プロジェクトでは、人材の育成、プレス発表、展示会での成果展示とともに技術移 転などを精力的に行い、この分野と技術の裙野を広げることに貢献しているが、終了後においても、プ ロジェクトで得た成果の実用化に向けた研究が、企業をまきこみながら継続されることを期待したい。

〔科学技術への貢献〕〔社会・経済への貢献〕 a + (十分な貢献が期待できる) 
4. その他特記すべき事項

$4-1$. 若手研究者支援

若手研究者や学生には、学術論文や国内外の学会での発表の機会が積極的に与えられた。その結果と して、若手研究者や学生の奨励賞などの受賞件数は 50 件に上った (2019.11.30 時点)。さらに、国内外 の著名な研究者や海外の若手研究者の招聘により、国際的な経験を積む機会が積極的に設けられると同 時に、国内外の研究機関との複数の共同研究が実施され、若手の国際的な視点の育成が図られている。

$4-2$ ．アウトリーチ活動

プロジェクトの積極的な紹介のために、Web サイトの充実、プレス発表、取材対応と一般誌への記事 掲載、杂誌でのプロジェクト特集号の出版、主催・共催の国際会議を含むシンポジウム開催、展示会へ の出展、新技術説明会など、70 件もの活動が行なわれた。世界的に著名な研究者の参加のもと、ICO24 (第 24 回国際光学委員会 2017.8) では、光コムの特別シンポジウムが共催され、関連して電気通信 大学において、一般公開の国際シンポジウムを開催することで成果普及に努めている。また、オープン キャンパス時には、中高生や一般に対するアウトリーチ活動も行われたが、長期的な視点からの人材育 成や、先端技術への理解醸成の観点からも、意義深い活動であったと判断される。

\section{5. 総合評価}

本プロジェクトは、エレクトロニクスと光技術との融合により、スペクトル強度が等間隔の櫛状に並 んだ先端的光源「光コム」を、基盤的かつ革新的な新技術群・機器「知的光シンセサイザ」へと進化さ せるとともに、科学技術から社会生活までの様々な応用に向けた先進的技術群を開発し、併せて、未踏 な分野における「革新的応用の開拓」を目指した。端的に言えば、最大の目標は、「光コム」という新し い光をいかに広範囲に利用するか、そしてそれを可能にする技術を確立するかであり、結果として、光 コムが幅広い分野で活用されることで、豊かな社会の実現に資することであったと言える。

先進的光源技術としては、・高繰り返し $\mathrm{Yb}$ ファイバコム光源、・デュアルコムファイバレーザー光源 などの新規光コム光源、・高精度かつ長期安定なモードフィルタリング技術などの光コム利用のための 基本技術、・複数の光コム間のコヒーレンス制御性を用いることで画期的に光波制御の自由度を高める コヒーレンスシンセサイザ技術、・これを活用して光コムの時間軸特性と横空間軸特性の制御への道を 拓いた光渦コムなど、光コムの物理的特性の深い理解に基づいた画期的な基礎技術が多く生み出され た。特に、高精度であっても使い易い、即ち汎用性のある光コム利用技術、制御技術の研究成果では、・ フィードフォワード法や、Dual-beat phase-lock 法の開発に基づいた「半整数光コム」およびオフセッ トフリーコムの開発、・励起光強度変調により光コムの全ての周波数制御を行う全光制御型光コムに関 する研究、・THz コムモードの間隙部分を補完しギャップレス化するギャップレス・デュアル $\mathrm{THz}$ コム 分光法、・高精度性を実現しながら測定データ量を大幅に削減する離散フーリエ変換 $\mathrm{THz}$ 分光法、・非 制御レーザーの利用を可能とするアダプティブサンプリング式デュアル $\mathrm{THz}$ コム分光法があげられる が、これらの技術は多様な応用システムへ実装され世界標準的に使われる可能性ある技術群であると評 価される。

革新的応用の開拓では、・複素光学特性を高速に評価可能な汎用的固体材料物性評価法、・機械的走查 
が不要で位相情報も取得できる分光エリプソメトリー、・高精度広ダイナミックレンジな瞬時 3 次元計 測、・デュアル光コム顕微鏡、・天文コムなど革新性に富んだ計測技術が得られた。

以上のように本プロジェクトの研究成果は広範囲な分野に及び、しかも、斬新で高い性能を実現して いる。プロジェクトに参画する若手研究者や学生が、高いモチベーションを維持しつつ、それぞれの研 究課題を十分に理解した上で研究を遂行したこと、研究総括および各グループリーダーのガバナンスが 機能し、若手が研究に勤しむ環境が提供され、これが彼らの成長に大きく貢献したことが高い成果に繋 がったと判断される。実際、研究成果の客観的評価の目安である論文数、発表件数、招待講演数、知的 財産権の数などは、各グループ、あるいはプロジェクト全体としても質・量ともに十分といえる研究成 果を上げたと評価できる。

一方、ERATO プロジェクトの真価は、プロジェクトで得られた成果が将来どのような社会・経済的 な価值形成に貢献寸るかという観点からも問われる。研究期間の後段では、得られた個々の研究成果 はプロジェクトを表象する成果としてまとめられ、この価值に繋げる道筋を描くための戦略的な情報 発信とともに、企業との共同研究など実用化に向けた活動が実施された。デユアルコム分光法を時間 領域分光法へと拡張して得られた汎用的な固体物性評価法、瞬時 3 次元形状測定法、デュアル光コム 顕微鏡では、それぞれ、高速高精度複素光学特性評価、撮像カメラ画角全域における奥行きサブマイ クロメートルの分解能、および強度・位相・蛍光・蛍光寿命計測において、製品開発に繋がる競争優 位性が確認され、潜在的なユーザーを意識した仕様のもと、応用分野側に一歩踏み出した研究開発が 行われた。実際、瞬時 3 次元形状測定法では、ダイナミックレンジ（精度／範囲）が 106 以上、時間 分解能数 $10 \mathrm{fs} \sim \mathrm{ps}$ （パルス幅に依存）、取得レート数 Mfps（繰り返し〜Gfps）の無走查計測を実証し た。また、ソフトマテリアル内部の非破壊測定や生物試料の位相像計測が可能である事も示し、将来 のユーザーに有用性を訴求した。デュアル光コム顕微鏡では、開発されたデュアルコム光源の利用に よるシステムの安定化・簡素化が試みられ、コスト面からもそのポテンシャルが評価された。特に、 デュアルコム分光を固体物性研究へ応用寸るという新しい着想を得て開発されたスーパー分光計で は、企業をメンバーに加え共同作業により、外磁場印加に対する光学応答特性、寸なわち磁気光学効 果を高速に評価する光コム分光計の製品プロトタイプとして、25nm の波長範囲を波長分解能 $0.01 \mathrm{~nm}$ 、ファラデー効果測定分解能 $0.01 \mathrm{deg}$ 、一点の測定時間 $7 \mathrm{msec}$ での高速測定を実証し、光コム 応用の社会実装に向けて大きな一歩を踏み出した。決してやさしい技術ではない光コムを実装し、 様々な物性計測に展開できる製品プロトタイプにまとめたことは、研究者と企業の密な連携の結果と 思われる。

プロジェクトが生み出した光コム関連基盤技術のみならず様々な応用技術や応用例は、やがて社会・ 経済に浸透し、その波及効果が現れるものと期待されるが、まだ研究の余地が残ったポテンシャルの高 い技術もあり、この成果を継続的に発展させるための活動が必要であろう。上述したが、コム自体の低 コスト化や提案された応用のニーズ顕在化によって、短期間に成果の社会実装が実現できる可能性もあ るので、今後とも、成果の発展や実用化に向けた研究が、企業をまきこみながら継続されることを期待 したい。プロジェクトにかかわった若手研究者や学生のもたらす人的波及効果が、継続的な光コム関連 技術の発展や実用化に大きく寄与することが期待されるが、成果を散逸させないためにも、光コムを主 軸とした新しいプロジェクトの創設を願うものである。

以上をもとに本プロジェクトを総括すると、ERATO の目的に適い戦略目標「情報デバイスの超低消 費電力化や多機能化の実現に向けた、素材技術・デバイス技術・ナノシステム最適化技術等の融合によ る革新的基盤技術の創成」の達成に資する十分な成果が得られたと判断される。 
ERATO 美濃島知的光シンセサイザプロジェクト事後評価（最終評価）報告書

〔総合評価〕 A+（十分な成果が得られた）

以上 